\title{
ALTERATIONS ON THE EVAPOTRANSPIRATION OF SUGARCANE CULTIVARS UNDER DISTINCT SALINITY LEVELS APPLIED IN THE FERTIGATION ${ }^{1}$
}

Doi:http://dx.doi.org/10.1590/1809-4430-Eng.Agric.v37n5p940-952/2017

\section{JOÃO V. TOLEDO", SÉRGIO ZOLNIER ${ }^{3}$, THIERES G. F. DA SILVA ${ }^{4}$, DAVI BOEHRINGER ${ }^{3}$, ANTONIO J. STEIDLE NETO ${ }^{5}$}

${ }^{2 *}$ Corresponding author. Universidade Federal de Viçosa/Viçosa - MG, Brasil. E-mail: jvitor_agr@yahoo.com.br

\begin{abstract}
The aim of this research was to evaluate the effect of distinct levels of salinity on the evapotranspiration of the RB867515, RB855453, RB92579 and RB928064 sugarcane cultivars. The evapotranspiration was monitored during daytime period under meteorological conditions influenced, mainly by cloud variations. The salinity values were established by addition of 0,50 , 100 and $150 \mathrm{mM}$ of Sodium Chloride $(\mathrm{NaCl})$ to the nutrient solution, which was applied by fertigation, in such way that the electrical conductivity (EC) of the leached solution was near 3, 6, 10 and $13 \mathrm{dS} \mathrm{m}^{-1}$, respectively. The increase of the $\mathrm{NaCl}$ concentration in the nutrient solution affected, significantly and in a linear manner, the evapotranspiration of all sugarcane cultivars, such that the days with low cloud provided the highest evapotranspiration values and the greater reduction among salinity levels. Analysis of the evapotranspiration accumulated during the daytime period showed that there were no significant differences among sugarcane cultivars and that, under the highest atmospheric water demand, the evapotranspiration decreased $48.5 \mathrm{~g}$ plant $^{-1} \mathrm{EC}^{-1}$. This value represents the average reduction of $5.1 \% \mathrm{EC}^{-1}$ when compared to the treatment without $\mathrm{NaCl}$, considering data of all cultivars.
\end{abstract}

KEYWORDS: efficient water use, Saccharum officinarum, saline stress, salinization.

\section{INTRODUCTION}

Data provided by Companhia Nacional de Abastecimento show that the area planted with sugarcane in 2015/2016 reached approximately 8.65 million hectares, indicating a change of 3.9\% less in cultivated area. However, the final result was higher, with a production of around 665.6 million tons, which corresponds to an increase of $4.9 \%$ when compared to data of $2014 / 2015$, and it was not only higher due to the water crisis that hit the country, mainly in the north/northeast region (CONAB, 2016).

The sugarcane, because of its $\mathrm{C} 4$ metabolism, is a plant that has high productivity rates under conditions of high temperature, solar radiation and water availability (Silva et al., 2011; Antunes et al., 2016). However, some regions in Brazil, which have climatic conditions characterized by adequate values of air temperature and solar radiation for sugarcane cultivation, present low precipitation. In this case, the use of brackish water and/or soluble fertilizers in irrigation events may promote or aggravate soil salinization (Willadino et al., 2011). Thus, salinization in areas cultivated with sugarcane has caused concerns regarding productivity and economic viability for the producer.

The saline stress causes several morphological and biochemical changes in plants. First, the salinity affects the osmotic potential, with characteristics of water stress occurrence, reducing water absorption and, consequently, transpiration. However, depending on the intensity and duration of this process, toxicity can be observed due to the accumulation of ions inside the cells (Munns \& Tester, 2008). In studies with sugarcane, the saline stress causes reduction of sprouting, dry matter, both shoot and root, leaf area, evapotranspiration, and other changes, such as chlorophyll content

\footnotetext{
${ }^{1}$ Extracted from the doctoral thesis of the first author. Scholarship granted by CAPES.

${ }^{3}$ Universidade Federal de Viçosa/ Viçosa - MG, Brasil.

${ }^{4}$ Universidade Federal Rural de Pernambuco/ Serra Talhada - PE, Brasil.

${ }^{5}$ Universidade Federal de São João Del Rei/ Sete Lagoas - MG, Brasil.

Received in: 7-14-2016

Accepted in: 5-15-2017
} 
and carotenoids (Santana et al., 2007; Willadino et al., 2011; Patade et al., 2011; Simões et al., 2016).

Higher values of temperature, air velocity and solar radiation, as well as low values of relative air humidity, are elements that favor greater evapotranspiration (Pereira et al., 2013), and the effects of salinity are intensified under these conditions (Munns \& Tester, 2008). In this context, studies that relate the meteorological variables to the salinity during the cultivation of sugarcane are scarce in the literature. In addition, knowledge of the salinity level, which does not significantly affect agricultural productivity, and more tolerant cultivars provide essential information for planting in regions where the soil or the irrigation water has a certain degree of salinity. Moreover, the knowledge acquired can generate information for genetic improvement (Pagariya et al., 2012; Augustine et al., 2015; Antunes et al., 2016).

As a result of the large volume of soil explored by the sugarcane root system, which can reach more than four meters deep (Laclau \& Laclau, 2009), there is a great spatial variation of the soil physical and chemical properties and the water movement inside it (Batista et al., 2015), being difficult to control the uniformity of the treatments application in studies about salinity under field conditions. In this sense, many studies described in the literature were conducted with planting in pots and, generally, with the application of different salts concentrations, such as sodium chloride $(\mathrm{NaCl})$ in the irrigation water, in order to quantify the influence of salinity in the growth and development of sugarcane (Plaut et al., 2000; Patade et al., 2011; Augustine et al., 2015; Simões et al., 2016) and different cultivars (Lima et al., 2014; Silva et al., 2015).

The aim of this research was to evaluate the salinity effect on the evapotranspiration behavior of four sugarcane cultivars under different meteorological conditions, characterized mainly by cloudiness changes, usual of typical days with high and mild values of solar radiation, air temperature and water vapor saturation pressure deficit.

\section{MATERIAL AND METHODS}

The experiment was carried out in a free-standing greenhouse without environmental controls, which was constructed in the Department of Agricultural Engineering (DEA) of the Federal University of Viçosa (UFV), Viçosa-MG. The greenhouse is located at latitude $20^{\circ} 45^{\prime} 45^{\prime \prime} \mathrm{S}$, longitude $42^{\circ} 52^{\prime} 04$ '” W and altitude of $690 \mathrm{~m}$.

The results were obtained using a completely randomized design in a 4 x 4 factorial scheme with three replications. The first factor consisted of four sugarcane cultivars (RB867515, RB855453, RB92579 and RB928064), and the second consisted of different levels of salinity, which were established by the addition of $0,50,100$ and $150 \mathrm{mM}$ of Sodium Chloride $(\mathrm{NaCl})$ to the fertigation water, so that the Electrical Conductivity (EC) of the leached solution remained close to $3,6,10$ and $13 \mathrm{dS} \mathrm{m}^{-1}$, respectively.

In total, 192 plants were grown in plastic vases during the experimental period, comprising 48 plants of each cultivar (Figure 1A). Thus, 12 plants of each cultivar were used at random to evaluate the effect of salinity levels on evapotranspiration in four measurement campaigns, and the mass variation in each vase was evaluated as an experimental unit. On the 12/13/2014, three mini stalks, containing one bud in each unit, were planted in plastic vases with a total volume of 15 liters, filled with $13 \mathrm{~L}$ of commercial substrate (Bioplant, Nova Ponte, MG) based of pine bark and rice, manure, sawdust, coconut fiber ash, gypsum and mineral complements (NPK and micronutrients). The mini stalks were removed from sugarcane plants (cane-plant) that were previously cultivated in conditions characterized by the absence of water and saline stresses. 


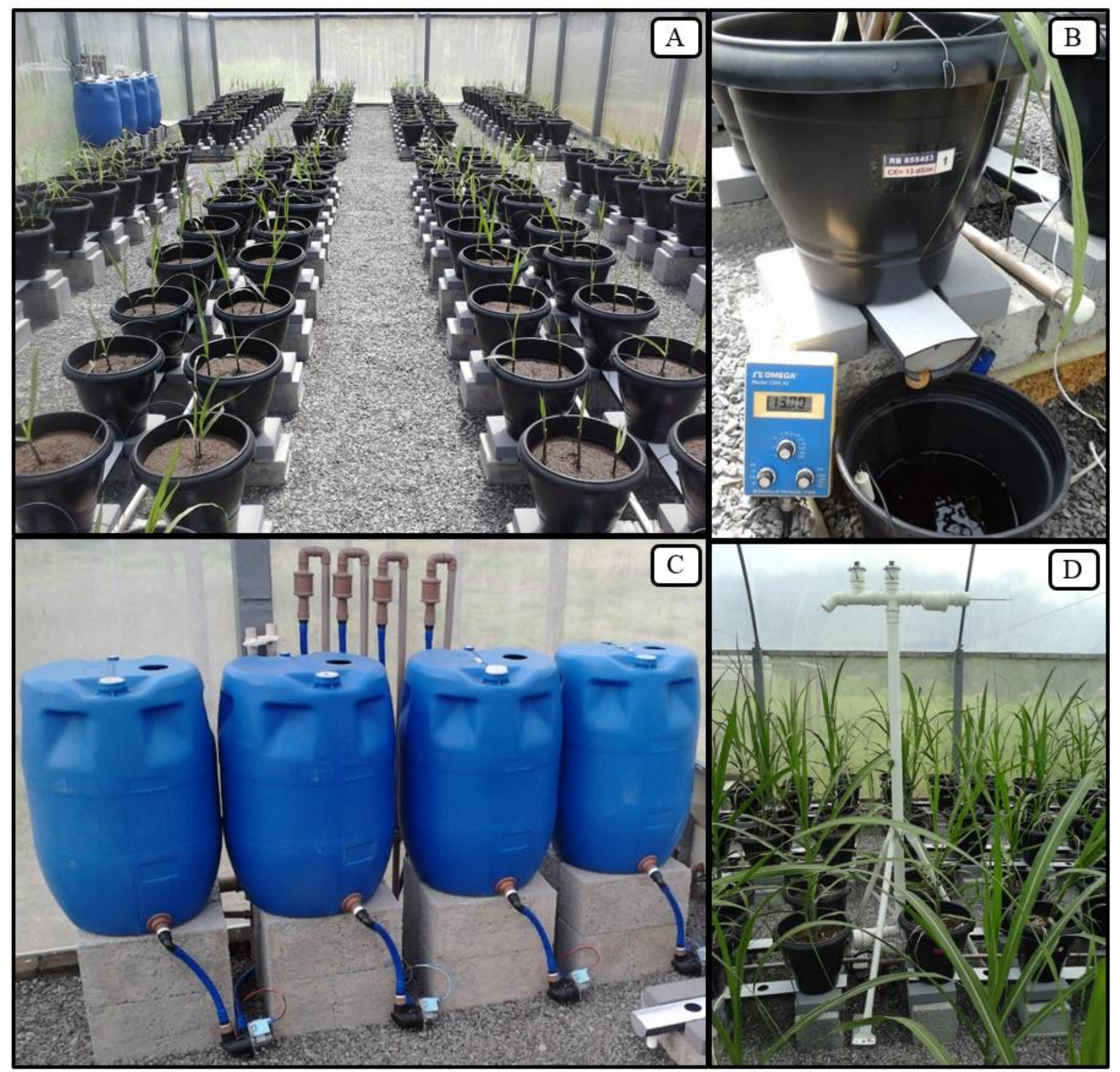

FIGURE 1. Sugarcane cultivation under greenhouse conditions (DEA/UFV, Viçosa-MG). General picture of the experiment at 15 DAP (A); EC measurements of the leached solution (B); reservoirs and micropumps for applying the four treatments $(\mathrm{C})$; and structure for installing the meteorological sensors in the cultivation environment (D).

At the bottom of the vases, a hole of $2.3 \mathrm{~cm}$ diameter was drilled to drain the nutrient solution. In addition, to prevent loss of the substrate, a plastic screen was placed on the bottom of the vase, which had $1 \mathrm{~mm}$ and $16 \mathrm{~cm}$ diameter mesh. Then, between the screen and the substrate, $500 \mathrm{ml}$ of charcoal was deposited to facilitate lateral drainage in the bottom of the cultivation vase.

Hydroponic profiles of polypropylene (Hidrogood, Taboão da Serra, SP) were installed under the vases to collect the nutrient solution drained in the crop rows, with $4 \%$ inclination. At the lower end of the profile, an orifice was drilled to place a PVC adapter, which was connected to a removable hose that was connected to the drainage system, to discard the surplus after performing the fertigation events. Periodically, the removable hose was disconnected from the drainage system and the leached nutrient solution collected in a four L vase for EC measurement (Figure 1B).

At 30 days after planting (DAP), thinning was carried out in the experimental area, maintaining only one plant per vase, from the elimination of those that did not show similar morphological characteristics. At 70 DAP, the treatments started, however, the total amount of 
$\mathrm{NaCl}$ was fractionated in the first fertigation events. During the growing period, the sugarcane tillers were removed periodically to leave only one stem in each vase. In addition, the plants were tied individually to avoid stalk falling over on days with strong winds.

During the cultivation of sugarcane, fertigation were carried out with a nutrient solution prepared manually, from the addition of identical volumes of two stock solutions A and B in the water, these being 50 times concentrated (Table 1). The resulting diluted solution was stored in four containers C1, C2, C3 and C4, with individual capacity of $100 \mathrm{~L}$ (Figure 1C). All the containers were periodically filled with the same nutrient solution, whose EC had a value close to $3 \mathrm{dS} \mathrm{m}^{-1}$. However, in the containers $\mathrm{C} 2, \mathrm{C} 3$ and $\mathrm{C} 4$ the respective amounts of $2.9,5.8$ and $8.7 \mathrm{~g} \mathrm{~L}^{-1}$ of NaCl were added, obtaining the final $\mathrm{EC}$ values of 6,10 and $13 \mathrm{dS} \mathrm{m}^{-1}$, respectively.

The $3 \mathrm{dS} \mathrm{m} \mathrm{m}^{-1}$ value of the nutrient solution used in the cultivation of sugarcane was based on the studies of Trentin et al. (2011), Boehringer et al. (2013) and Batista et al. (2015), and the amounts of $\mathrm{NaCl}$ in studies carried out with the aim of evaluating the effect of salinity on sugarcane growth (Plaut et al., 2000; Patade et al., 2011; Willadino et al., 2011; Simões et al., 2016). The EC monitoring was performed manually with a portable conductivity meter (CDH-42 model, Omega, Stamford, CT, USA).

TABLE 1. Composition of the stock solutions A and B, 50 times concentrated, with the respective fertilizers, amount dissolved in 100L of water, and nutrient concentration. This solution was modified, considering the Johnson's nutrient solution as reference (Johnson et al., 1957).

\begin{tabular}{|c|c|c|c|c|c|}
\hline \multicolumn{3}{|c|}{ Preparation of stock solution 50 times concentrated } & \multicolumn{3}{|c|}{ Nutrient solution* } \\
\hline Solution & Salts/Fertilizers & $\begin{array}{l}\text { Concentration } \\
\text { g } 100 \mathrm{~L}^{-1}\end{array}$ & Nutrient & $\begin{array}{l}\text { Conce } \\
\mathrm{mg} \mathrm{L}^{-1}\end{array}$ & $\begin{array}{l}\text { tration } \\
\mathrm{mM} \mathrm{L}^{-1}\end{array}$ \\
\hline \multirow{7}{*}{ A } & Potassium nitrate & 500 & $\mathrm{~N}-\mathrm{NH}^{4+}$ & 21 & 1.53 \\
\hline & Hydro calcium nitrate & 5500 & $\mathrm{~N}-\mathrm{NO}^{3-}$ & 129 & 9.24 \\
\hline & & & $\mathrm{K}$ & 344 & 8.80 \\
\hline & Purified monoammonium phosphate & 900 & $\mathrm{Ca}$ & 168 & 4.19 \\
\hline & Magnesium sulphate & 2000 & $\mathrm{Mg}$ & 40 & 1.63 \\
\hline & Potassium chloride & 3000 & $\mathrm{P}$ & 47 & 1.53 \\
\hline & Copper sulphate & 1.0 & $\mathrm{~S}$ & 52 & 1.62 \\
\hline \multirow[t]{6}{*}{ B } & Zinc sulphate & 3.5 & $\mathrm{Cu}$ & 0.05 & 0.001 \\
\hline & Manganese sulphate & 10.0 & $\mathrm{Zn}$ & 0.16 & 0.002 \\
\hline & Boric acid & 10.0 & Mn & 0.48 & 0.009 \\
\hline & Sodium molybdate & 1.0 & B & 0.34 & 0.032 \\
\hline & Ferrilene & 300 & Mo & 0.11 & 0.001 \\
\hline & & & $\mathrm{Fe}$ & 3.61 & 0.065 \\
\hline
\end{tabular}

*-Values referring to dilution of $0.03 \mathrm{~L}$ of both solutions $\mathrm{A}$ and $\mathrm{B}$ to one liter of water. At this dilution, the electrical conductivity of the solution will be approximately $3 \mathrm{dS} \mathrm{m}^{-1}$.

The salinity levels, implemented in the nutrient solution, were applied through flexible microtubes that were derived from PVC pipes. In this system, the frequency and duration of the fertigation events were established by a microcontroller (Duemilanove model, Arduino, Italy), associated to a relay board, responsible for the activation of four micro pumps connected to the containers C1, C2, C3 and C4. During the experiment period, the amount applied was altered according to crop growth and meteorological variations of the growing environment.

The volume of nutrient solution applied was always superior to evapotranspiration, providing a leached fraction greater than $25 \%$ and EC values close to those recommended in the treatments $\left.( \pm 0.5 \mathrm{dS} \mathrm{m})^{-1}\right)$. The fertigation events occurred daily at $6 \mathrm{p} . \mathrm{m}$., using a flow rate of $0.06 \mathrm{~L} \mathrm{~min}^{-1}$. This schedule was adopted so that the next day there would be no influence of the drainage at the weighing of the vases. 
Each hydroponic profile was $2.6 \mathrm{~m}$ long and collected the drainage from six vases. In total, 32 profiles were installed to drain the 192 plants cultivated in the greenhouse. In order to organize the treatments with different levels of salinity and cultivars, the spacing of $0.40 \mathrm{~m}$ between two planting lines (profiles) and $0.50 \mathrm{~m}$ between plants positioned in the drainage profile were used, constituting, therefore, a group with 12 plants of the same cultivar that were fertigated by the same PVC pipe.

The measurements of the meteorological variables in the growing environment were carried out by four electronic sensors installed in a structure constructed from PVC pipes, connections with $50 \mathrm{~mm}$ diameter and white coloration (Figure 1D), as used by Batista et al. (2015).

Inside the upper part of the structure, a temperature and relative humidity sensor (HMP60 model, Vaisala, Woburn-MA, USA) was installed. Thus, the sensitive elements of this sensor were protected from the direct incidence of the sun's rays and under a ventilation rate of $5 \mathrm{~m} \mathrm{~s}^{-1}$. In this system, the air was continuously aspirated through an axial fan installed in the lower part of the PVC structure. In contrast, in the upper part of the structure, sensors were installed to measure global solar radiation (Piranômetro, LI-200SA model, Li-Cor, Lincoln-NE, USA) and photosynthetically active radiation (Quantum, LI-190SA model, Li-Cor, Lincoln-NE, USA). Finally, on the opposite side of the conjugate temperature and relative humidity sensor, a hot wire anemometer (FMA-903-I model, Omega, Stamford-CT, USA) was installed to measure air velocity.

The management of data acquisition process and storage from electronic sensors was carried out through a program developed in $\mathrm{C}++$ language (software Builder 6.0 version, Borland ${ }^{\mathrm{TM}}$ ). This program was installed in a microcomputer that communicated with analog data acquisition modules (LR-7018 model, LR Informática Industrial, Porto Alegre-RS), where the sensors responsible for the measurements of the meteorological variables in the growing environment were connected. The readings of the data occurred at intervals of five seconds, and the averages of 12 readings were stored in each minute.

The crop evapotranspiration was measured with an electronic scale (Tecnal, Piracicaba, SP), which showed individual capacity for $12 \mathrm{~kg}$ and accuracy of $0.1 \mathrm{~g}$. The mass variation of the individual crop system, consisting of plastic vase, substrate, water and a sugarcane plant, was obtained throughout the daytime period. The results were integrated in hourly intervals between 8 a.m. and 5 p.m., which corresponds to the daytime period with higher evapotranspiration, due to the higher incidence of solar radiation.

Four campaigns of evapotranspiration measurements were conducted, being carried out at 97 , 105, 118 and 132 DAP. These dates were chosen as representative of days with different evapotranspiration values, due to the reduced (97 and 105 DAP) and intense cloudiness (118 and 132 DAP). As the meteorological data of the growing environment were different in those days, the analyzes were carried out separately, showing the hourly variation of the evapotranspiration rate between 8 a.m. and 5 p.m. However, analysis of variance (ANOVA) was carried out for daytime accumulated evapotranspiration and between 11 a.m. and 2 p.m., with Tukey test applied later for significant results. Statistical analyzes were carried out using the ASSISTAT program.

The plant leaf area was estimated by the sigmoidal model with three parameters, from measurements of leaf width, length and form factor, the last being determined by destructive measurements at the end of the experiment. The data required for the application of the model were obtained in seven biometrics campaigns during the sugarcane cultivation period, allowing to estimate the leaf area on the days of evapotranspiration measurement.

\section{RESULTS AND DISCUSSION}

Figure 2 shows the daytime behavior of air temperature $\left(\mathrm{T}_{\text {air }}\right)$, the water vapor saturation pressure deficit in the air $\left(\mathrm{VPD}_{\text {air }}\right)$ and global solar radiation $\left(\mathrm{R}_{\mathrm{g}}\right)$ during the measurement campaigns conducted at 97, 105, 118 and 132 days after planting (DAP). The average daytime values of $\mathrm{T}_{\mathrm{air}}, \mathrm{VPD}_{\text {air }}$ and $\mathrm{R}_{\mathrm{g}}$ were $27.1^{\circ} \mathrm{C}, 15.9 \mathrm{hPa}$ and $313 \mathrm{~W} \mathrm{~m}^{-2}$, respectively for $97 \mathrm{DAP}$; 
$28.2^{\circ} \mathrm{C}, 16.4 \mathrm{hPa}$ and $325 \mathrm{~W} \mathrm{~m}^{-2}$, for $105 \mathrm{DAP} ; 21.8^{\circ} \mathrm{C}, 7.3 \mathrm{hPa}$ and $162 \mathrm{~W} \mathrm{~m}^{-2}$, for $118 \mathrm{DAP}$; and $24^{\circ} \mathrm{C}, 7.8 \mathrm{hPa}$ and $130 \mathrm{~W} \mathrm{~m}^{-2}$, for $132 \mathrm{DAP}$.
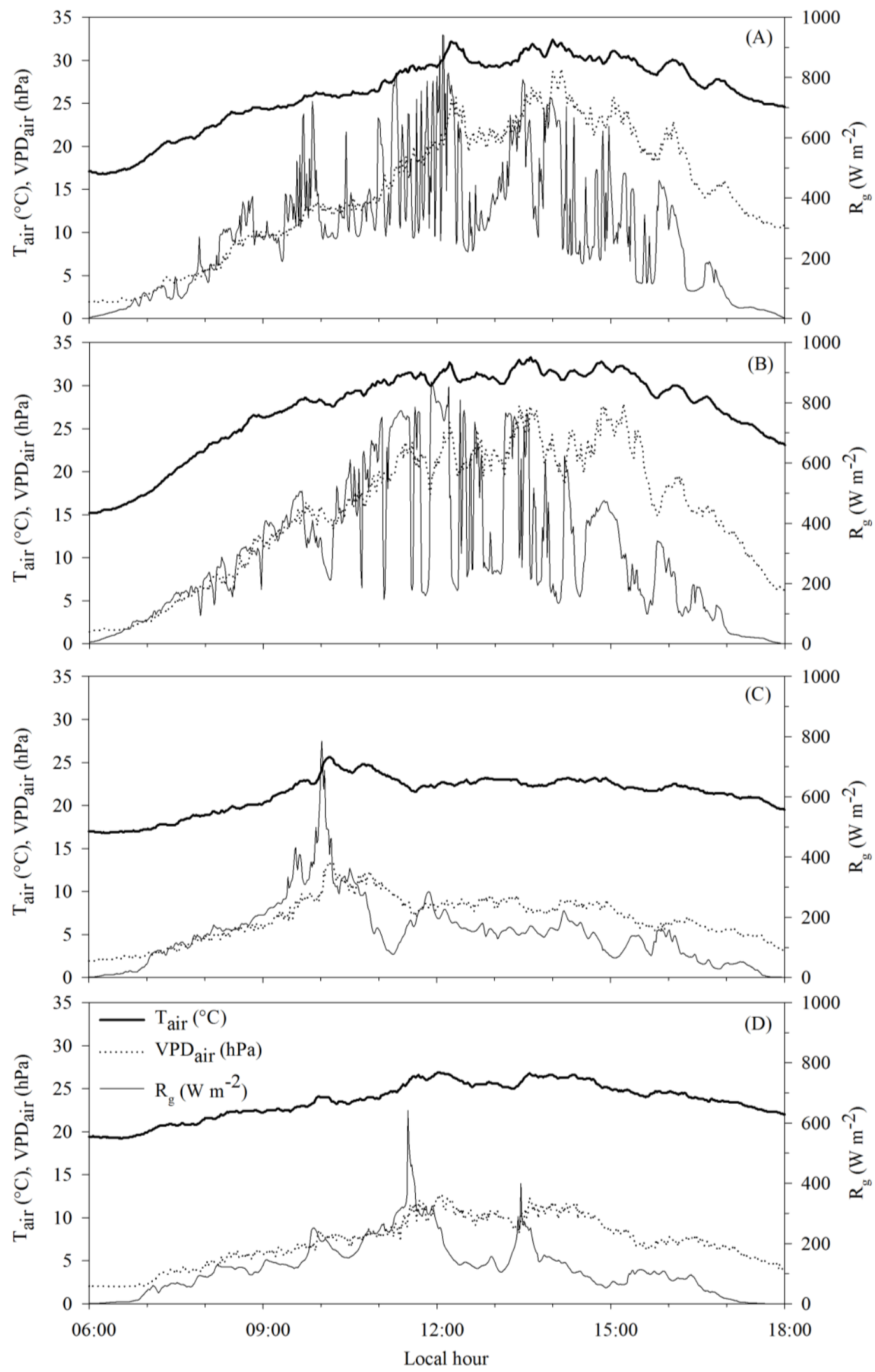

FIGURE 2. Changes of the air temperature $\left(\mathrm{T}_{\text {air }}\right)$, water vapor saturation pressure deficit in the air $\left(V_{P D}\right.$ air $)$ and global solar radiation $\left(\mathrm{R}_{\mathrm{g}}\right)$. Measurements were carried out at the $97(\mathrm{~A})$, 105 (B), 118 (C) and 132 (D) days after planting. 
In these measurement campaigns, the meteorological conditions were similar to 97 and 105 DAP, being typical of days characterized by reduced cloudiness. In contrast, similar conditions established by high cloudiness were observed at 118 and 132 DAP.

When the mentioned variables have higher values, as observed at 97 and 105 DAP, favorable conditions are established for intensification of the crop evapotranspiration (Silva et al., 2011; Trentin et al. 2011). In the specific case of these days, the values of $T_{a i r}, V_{P D}$ air and $R_{g}$ were generally higher in the period between 11 a.m. and 2 p.m.

The analysis of the total evapotranspiration in the daytime period (ETcd) showed that there were no significant differences between the sugarcane cultivars and that the regression equation that best fit the data of the ETcd in function of the salinity was linear. Moreover, this fact was observed in the four measurement campaigns (Figure 3). The salinity caused a decrease of the ETcd for the four sugarcane cultivars, regardless of the meteorological conditions.

Based on the angular coefficient of the regression line and considering the four cultivars, the average values of daytime evapotranspiration reduction for each increment of the electrical conductivity of the fertirrigation solution were $34.9,48.5,21.3$ and $19.8 \mathrm{~g} \mathrm{plant}^{-1} \mathrm{EC}^{-1}$, respectively at 97, 105, 118 and 132 days after planting (DAP).

Based on the regression equations, an average ETcd reduction of approximately $24 \%$ is observed, considering the EC change from 3 to $8 \mathrm{dS} \mathrm{m}^{-1}$, taking as reference the average value of ETcd obtained in the four measurements. This result is similar to that found by Santana et al. (2007), which evaluated the effect of salinity on sprouting and initial development of SP80-1842 sugarcane cultivar, whose evaluation period was restricted to 38 DAP and planting was carried out in three soils of different textures. The authors verified that irrigation water with EC of $8 \mathrm{dS} \mathrm{m}^{-1}$ caused the greatest daily reduction in evapotranspiration by about $20 \%$ for sandy soil.

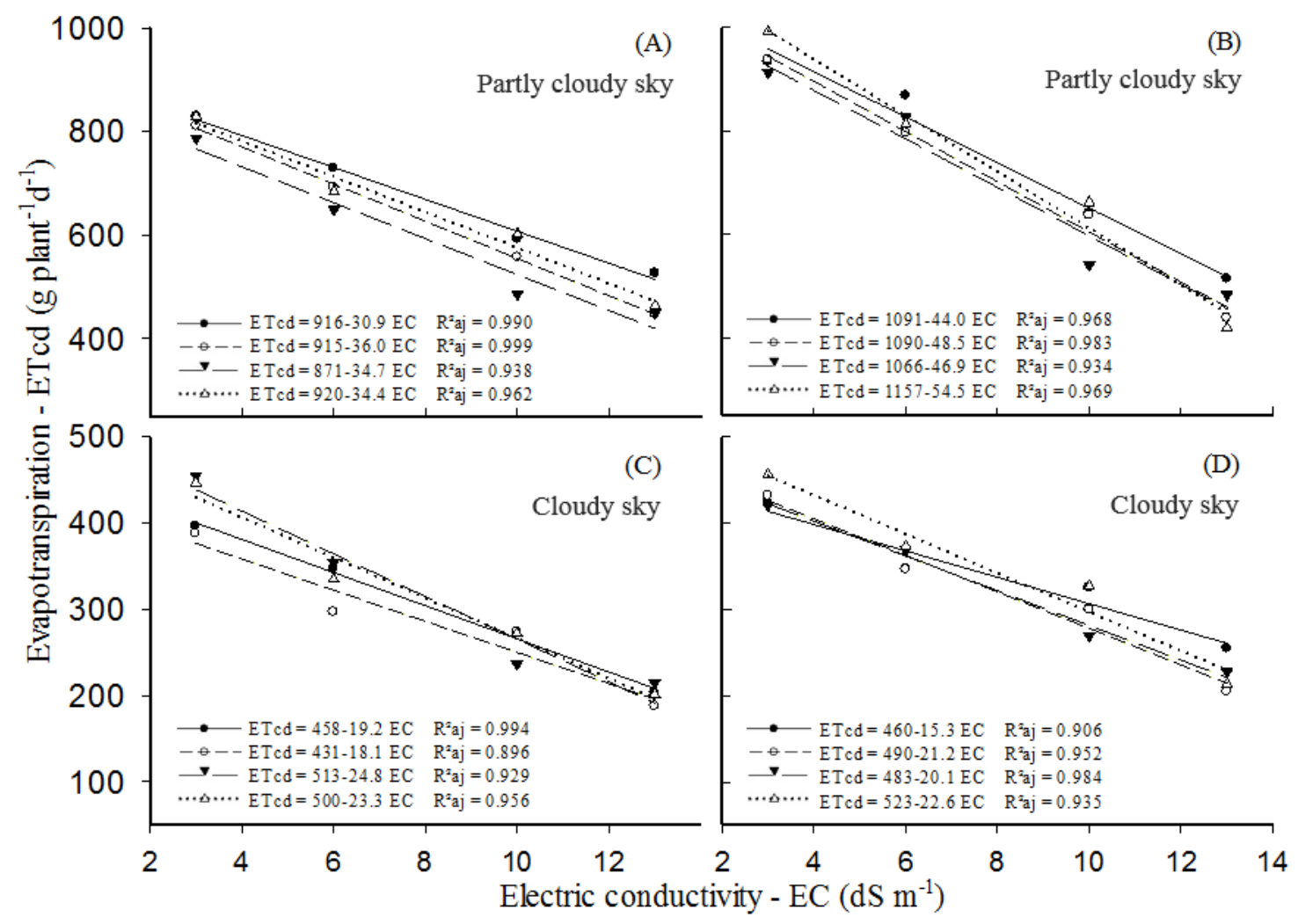

FIGURE 3. Accumulated evapotranspiration in the daytime period (ETcd) for sugarcane cultivars

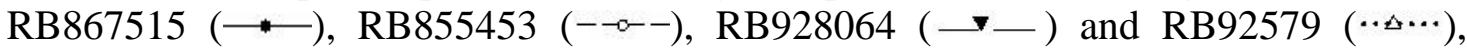
subjected to different salinity levels. Measurements were carried out at the 97 (A), 105 (B), 118 (C) e 132 (D) days after planting under meteorological conditions partly and completely cloud $(\mathrm{p}<0,05)$. 
By adding the $\mathrm{NaCl}$ and $\mathrm{CaCl}_{2}$ salts in the irrigation water, Plaut et al. (2000) investigated the effect of five EC values $\left(1,2,4,8\right.$ and $12 \mathrm{dS} \mathrm{m}^{-1}$ ) on the transpiration of H65-7052 (less tolerant) and H69-8235 (more tolerant) cultivars, between 60 and 128 DAP. The authors measured the individual daily transpiration of the plants in the last 10 days of the experiment and verified values in the order of 1150 (H69-8235) and of $850 \mathrm{~g}$ of plant $^{-1}$ (H65-7052), which are close to those obtained in the present study for treatment with $3 \mathrm{dS} \mathrm{m}^{-1}$.

Similarly, Plaut et al. (2000) also found a linear tendency for the decrease of transpiration with the increase of EC. In addition, a reduction in transpiration from the first to the last EC level by about 65 and 82\% was observed for H69-8235 and H65-7052 cultivars, respectively. These higher reductions can be attributed to the typical values of air temperature observed by the authors in the greenhouse, which were 23 and $35^{\circ} \mathrm{C}$, respectively for the nighttime and daytime periods.

Considering that salinity mainly affects the osmotic potential (Munns \& Tester, 2008), in such a way as to hinder the absorption of water by the roots, the results presented here can, in a way, be compared to those of water stress available in the literature. In addition, there are few researches carried out to evaluate the effect of salinity on sugarcane evapotranspiration.

Trentin et al. (2011) evaluated the effect of water stress on RB867515 cultivar at 125 DAP, verifying reductions in plant transpiration in relation to non-stress treatment, of 28.1 and $63.3 \%$ for the matrix potentials around -474 and $-1272 \mathrm{kPa}$, respectively. The value of $28.1 \%$ is very close to the average reduction of $29 \%$ in ETcd, verified for the four cultivars in the this experiment, corresponding to the salinity increase from 3 to $9 \mathrm{dS} \mathrm{m}^{-1}$, the last value being estimated through the equations shown in Figure 3.

Analyzing the days with lower cloudiness, the highest ETcd value was measured at 105 DAP (Figure 3B) for the EC of $3 \mathrm{dS} \mathrm{m}^{-1}$, being about $14 \%$ higher than that obtained at 97 DAP (Figure $3 \mathrm{~A})$. As the meteorological conditions in the growing environment were similar these days, this difference can be attributed to the increase in leaf area between the measurement campaigns, which were 0.59 and $0.67 \mathrm{~m}^{2}$ at 97 and $105 \mathrm{DAP}$, respectively. Most of the sugarcane transpiration occurs in the leaves, where the stomata are responsible for controlling the loss of water to the atmosphere. This control becomes evident when the average values of the ETcd for the EC of $13 \mathrm{dS} \mathrm{m}^{-1}$ were observed, which were respectively 471.9 and 463.6 g plant $^{-1}$ at 97 and 105 DAP, indicating higher water stress under this level of salinity.

At the days of greatest cloudiness, the ETcd was on average about $3 \%$ higher for 132 DAP (Figure 3D) in relation to the $118 \mathrm{DAP}$ (Figure 3C), considering only EC of $3 \mathrm{dS} \mathrm{m}^{-1}$. However, this same ratio was approximately $10 \%$ higher for the EC of $13 \mathrm{dS} \mathrm{m}^{-1}$. The change in ETcd for both EC levels, in addition to being related to the increase in leaf area, can also be attributed to differences in $\mathrm{T}_{\text {air }}$ and $\mathrm{VPD}_{\text {air }}$ that were slightly greater in the range from 12 p.m. to 4 p.m. (Figure 2, 132 DAP).

Although the cultivars did not show significant differences for the evapotranspiration values accumulated in the daytime period (Figure 3), different behaviors were observed in the hourly values of the evapotranspiration rate during the daytime period, which will be presented only for the measurements carried out at 105 and 118 days after planting (DAP).

Figures 4 and 5 illustrate the changes in hourly evapotranspiration rate (ETch) for RB867515, RB855453, RB92579 and RB928064 sugarcane cultivars, respectively for representative meteorological conditions of partially cloudy days (105 DAP) and with total cloudiness (118 DAP), except for a brief radiation peak at 10 a.m.

The measurements were conducted continuously over the period from 8 a.m. to 5 p.m. As can be seen, from the meteorological data of the growing environment (Figure 2), the changes in cloudiness had a marked effect on global solar radiation, air temperature, and water vapor saturation pressure deficit during daytime period when evapotranspiration measurements were carried out. Thus, the evapotranspiration followed the demand for water from the atmosphere, presenting a distinct behavior in these two days, and at 105 DAP, the maximum values were verified near midday while the ETch decreased continuously from the morning to 118 DAP. This was due to the 
approach of higher density clouds that obstructed the incidence of solar radiation in the plants. From midday to $118 \mathrm{DAP}$, the values of $\mathrm{R}_{\mathrm{g}}, \mathrm{T}_{\text {air }}$ and $\mathrm{VPD}_{\text {air }}$ were lower than $200 \mathrm{~W} \mathrm{~m}^{-2}, 23^{\circ} \mathrm{C}$ and 8 $\mathrm{hPa}$, respectively.

First, in Figure 4, regardless of the cultivar, the highest daytime amplitudes of ETch are observed for the EC of $3 \mathrm{dS} \mathrm{m}^{-1}$. Thus, Thus the evapotranspiration followed the demand of water from the atmosphere. According to Pereira et al. (2013), the solar radiation is mainly responsible for the increase in evapotranspiration. In contrast, in spite of the alteration of the meteorological elements throughout the daytime period, more stable values of ETch were verified for the EC of $13 \mathrm{dS} \mathrm{m}^{-1}$, which suggests the intense performance of the stomatal control by the plants due to the decrease of water absorption with increase of salinity.
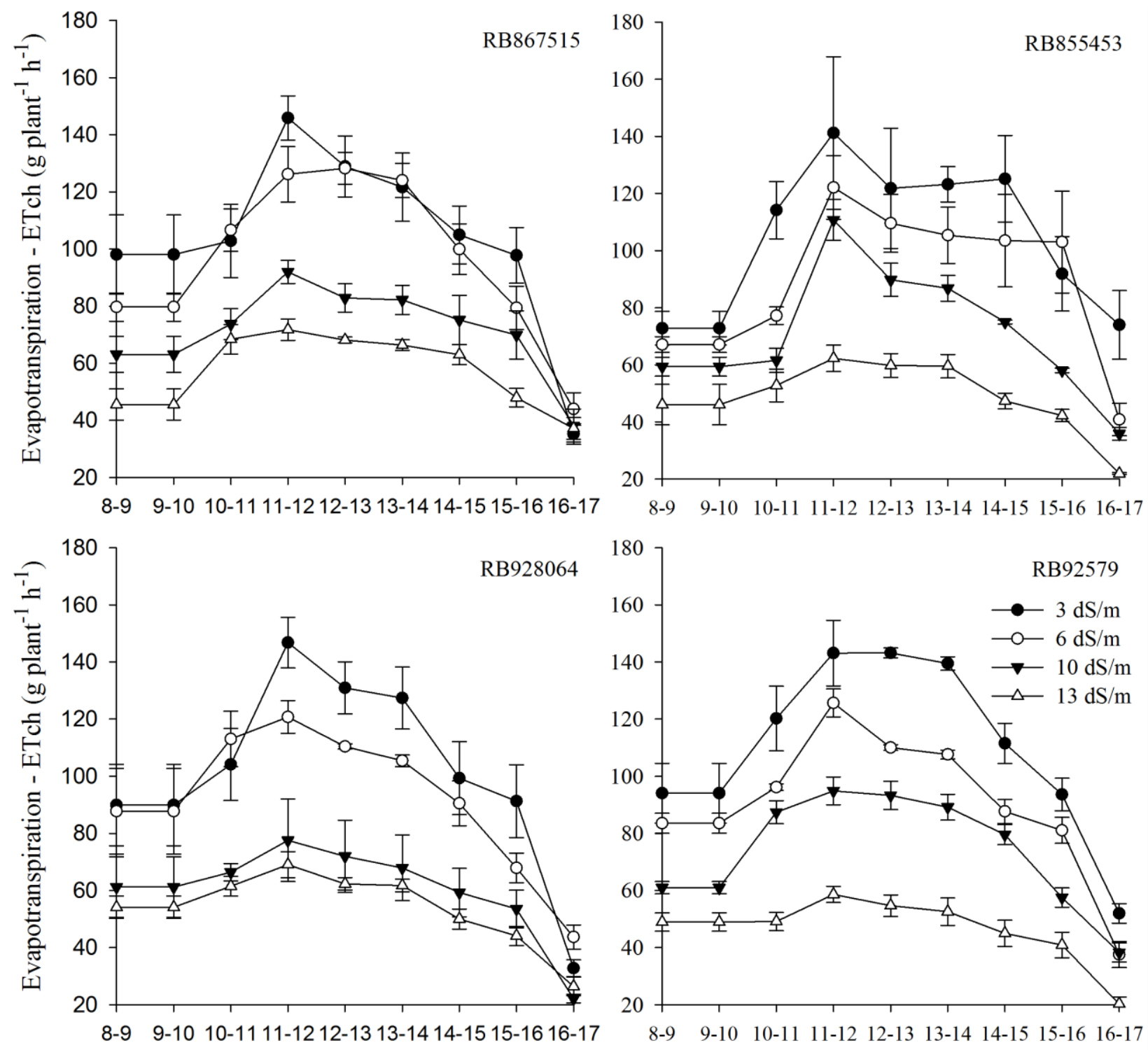

Period

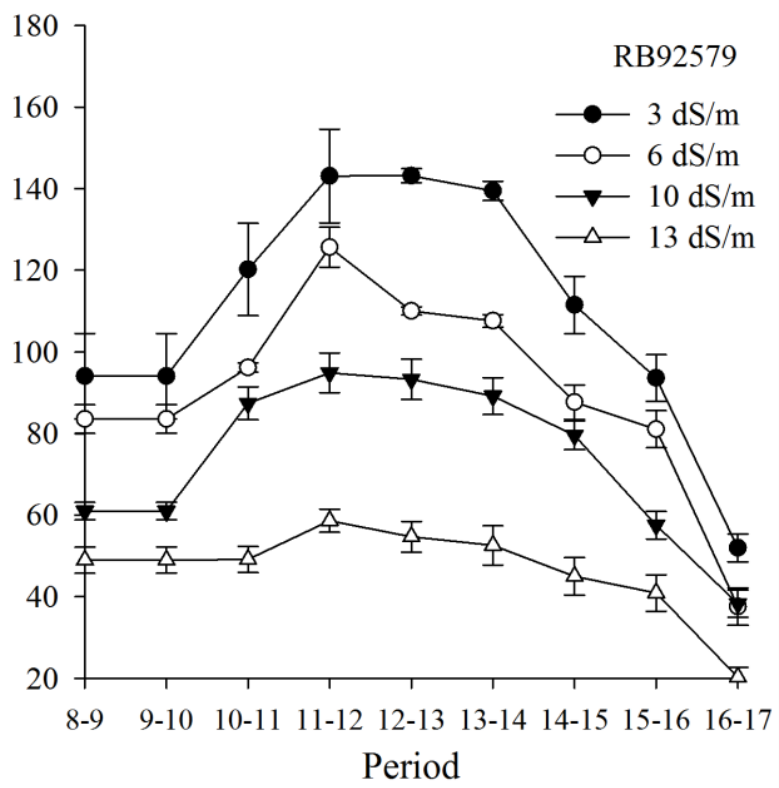

FIGURE 4. Changes in hourly evapotranspiration rate (ETch) for RB867515, RB855453, RB928064 and RB92579 cultivars, which were subjected to four salinity levels at 105 DAP. 

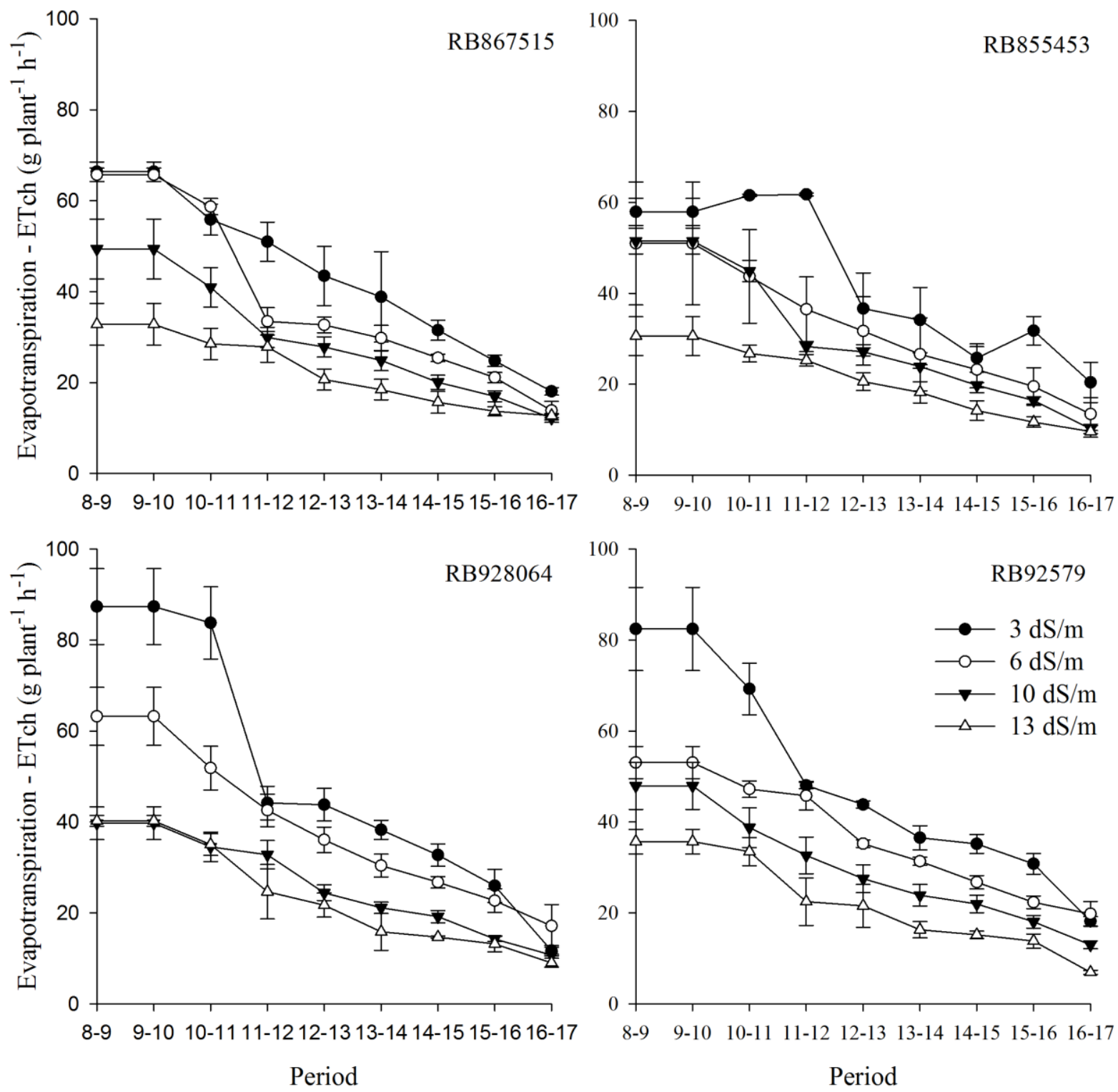

FIGURE 5. Changes in hourly evapotranspiration rate (ETch) for RB867515, RB855453, RB928064 and RB92579 cultivars, which were subjected to four salinity levels at 118 DAP.

This behavior is an indicative that the salinity level affected the ability of these cultivars to absorb water in response to atmospheric demand. The results found by Trentin et al. (2011) also showed that the highest rates of evapotranspiration occurred when RB867515 cultivar was not under water stress, and that incident solar radiation was the main environmental variable responsible for the change in ETch values, and this response is more evident in plants without stress.

In general, for all cultivars and salinity levels, the maximum value of evapotranspiration is observed in the period from 11 a.m. to 2 p.m., when the global solar radiation is close to $800 \mathrm{~W} \mathrm{~m}^{-2}$. The RB867515 cultivar showed similarity in the ETch values for treatments corresponding to 3 and $6 \mathrm{dS} \mathrm{m}^{-1}$, which may be a change in metabolism to tolerate the salinity. The RB928064 cultivar also showed an approximation of ETch values for 3 and $6 \mathrm{dS} \mathrm{m}^{-1}$, as well as for ETch values with 10 and $13 \mathrm{dS} \mathrm{m}^{-1}$.

Willadino et al. (2011), when evaluating the RB867515 and RB863129 cultivars after 30 days of application of eight levels of $\mathrm{NaCl}$, verified that the $\mathrm{RB} 867515$ had the greatest reduction in the chlorophyll content with the increase of the $\mathrm{NaCl}$ concentration. In addition, the intensification of the enzyme action of the antioxidative system was verified, for the levels of 50 to $100 \mathrm{mM}$ of $\mathrm{NaCl}$. 
These authors mentioned that the reduction of chlorophyll content and the increase of antioxidative enzymes are considered as mechanisms capable of tolerating stresses, such as that produced by $\mathrm{NaCl}$. In this study, variations in evapotranspiration rates, close to those found for the condition that did not have $\mathrm{NaCl}$ addition, were also observed for the RB867515 at the level of 50 $\mathrm{mM}$ of $\mathrm{NaCl}$.

In Figure 5, the evapotranspiration rate had its greatest variation according to the peak of global solar radiation $\left(800 \mathrm{~W} \mathrm{~m}^{-2}\right.$ near $\left.10 \mathrm{am}\right)$. The RB928064 and RB92579 cultivars showed the highest rates at the beginning of the daytime period for the EC of $3 \mathrm{dS} \mathrm{m}^{-1}$, however, from the period between 11 a.m. and 12 p.m., ETch values were lower and closer to those obtained under the other treatments, and the RB928064 again had ETch values very close to those found for EC of 10 and $13 \mathrm{dS} \mathrm{m}^{-1}$.

The results indicate that, under meteorological conditions influenced by the high cloudiness, the evapotranspiration rates are very similar between the different levels of salinity, which makes it difficult to identify this effect on the evaluated cultivars. Therefore, effect measurements of saline stress in water use should be avoided on cloudy days, as there is an approximation of the evapotranspiration lines corresponding to the different levels of salinity.

When ETch values are accumulated only for the times when the greatest demand for water in the atmosphere occurs, it is possible to identify differences in the effect of salinity levels in the evapotranspiration of the four sugarcane cultivars. Table 2 shows the results of the interaction between the cultivar factors and the level of salinity in the evapotranspiration $\left(\mathrm{g} \mathrm{plant}^{-1}\right)$ that occurred between 11 a.m. and 2 p.m., under conditions of low cloudiness.

The evapotranspiration of the RB867515 cultivar was not significantly affected when the salinity level increased from 3 to $6 \mathrm{dS} \mathrm{m}^{-1}$. In contrast, evapotranspiration of RB855453, RB92579 and RB928064 cultivars had significant reduction with this alteration of salinity. This result indicates that, from the point of view of water use and at relatively low EC levels, the RB867515 cultivar is less sensitive to saline stress than other sugarcane cultivars. However, for salinity levels of 10 and $13 \mathrm{dS} \mathrm{m}^{-1}$, the evapotranspiration accumulated in the period of higher water demand was statistically different from that observed for the EC of $3 \mathrm{dS} \mathrm{m}^{-1}$, independent of the evaluated cultivar.

Thus, the most pronounced effect of salinity on days characterized by the higher demand of water in the atmosphere (Figure 4) compared to those with higher cloudiness is evident (Figure 5). As the increase in the concentration of soluble salts near the root system decreases the osmotic potential of the substrate solution, this fact will hinder the water flow in the soil-plant-atmosphere direction (Munns \& Tester, 2008). Thus, days characterized by a low cloudiness favor the evapotranspiration process and, consequently, the plants that are more sensitive to the salinity effect cannot absorb the same amount of water in the root system to restore transpiration in the leaves.

TABLE 2. Interactions among sugarcane cultivars and salinity levels for accumulated evapotranspiration $\left(\mathrm{g}\right.$ plant $\left.{ }^{-1}\right)$ during the period of $11 \mathrm{a} . \mathrm{m}$. and $2 \mathrm{p} . \mathrm{m}$. The salinity levels were determined by the electrical conductivity of the leached nutrient solution after fertigation.

\begin{tabular}{|c|c|c|c|c|c|}
\hline \multirow{2}{*}{ Cultivar } & \multicolumn{4}{|c|}{ Electrical conductivity $\left(\mathrm{dS} \mathrm{m}^{-1}\right)$} & \multirow{2}{*}{-Average } \\
\hline & 3 & 6 & 10 & 13 & \\
\hline$\overline{\mathrm{RB} 867515}$ & $396.4 \mathrm{a} \mathrm{A}$ & 378.4 a A & 257.1 a b B & $206.3 \mathrm{a} \mathrm{B}$ & 309.5 \\
\hline RB855453 & 386.2 a A & 337.1 a A B & 287.4 a B & 181.6 a C & 298.1 \\
\hline RB928064 & $405.1 \mathrm{a} \mathrm{A}$ & 336.6 a B & $217.4 \mathrm{~b} \mathrm{C}$ & 193.0 a C & 288.0 \\
\hline RB92579 & 425.7 a A & $343.3 \mathrm{a} \mathrm{B}$ & 277.3 a C & 165.9 a D & 303.0 \\
\hline Average & 403.4 & 348.8 & 259.8 & 186.7 & 299.7 \\
\hline
\end{tabular}

Averages followed by different lower case letters in column or capital letters in line do not differ from each other by Tukey test $(\mathrm{p}<0.01)$ 


\section{CONCLUSIONS}

The $\mathrm{NaCl}$ concentration in the fertigation water significantly and linearly affected the accumulated evapotranspiration in the daytime period of all sugarcane cultivars, and the days of lower cloudiness provided the highest values of evapotranspiration and the highest reductions between salinity levels.

The analysis of the total evapotranspiration in the daytime period showed that there were no significant differences between the sugarcane cultivars and that, on the day of greater demand of water in the atmosphere, the reduction of evapotranspiration accumulated in the daytime period was $5.1 \% \mathrm{EC}^{-1}$ in relation to the treatment without $\mathrm{NaCl}$, considering all the cultivars.

The evapotranspiration accumulated in the period of greatest demand of water by the atmosphere, between 11 a.m. and 2 p.m., and on days with little or no cloudiness, should be used preferably for the comparative analysis of the saline stress effect on water use by different sugarcane cultivars.

\section{ACKNOWLEDGEMENTS}

This research was carried out with the financial resources of the Foundation for Research Support of the State of Minas Gerais - FAPEMIG (APQ-00408-14). The first author would also like to thank the Coordination of Improvement of Higher Personnel Education (CAPES) for the scholarship and the Federal University of Viçosa, through the Graduate Program in Agricultural Meteorology, for the opportunity to obtain the title of Doctor.

\section{REFERENCES}

Antunes WR, Schöffel ER, Silva SDdosA, Eicholz E, Härter A (2016) Adaptabilidade e estabilidade fenotípica de clones de cana-de-açúcar. Pesquisa Agropecuária Brasileira 51(2):142148.

Augustine SM, Narayan JA, Syamaladevi DP, Appunu C, Chakravarthi M, Ravichandran V, Subramonian N (2015) Erianthus arundinaceus HSP70 (EaHSP70) overexpression increases drought and salinity tolerance in sugarcane (Saccharum spp. hybrid). Plant Science 232:23-34.

Batista ELdaS, Zolnier S, Ribeiro A, Lyra GB, Silva TGFda, Boehringer D (2015) Avaliação do efeito do estresse hídrico no crescimento de cultivares de cana-de-açúcar usando um sistema automático de fertirrigação. Engenharia Agrícola 35(2):215-229.

Boehringer D, Zolnier S, Ribeiro A, Steidle Neto AJ (2013) Determinação do fluxo de seiva na cana-de-açúcar pelo método do balanço de energia caulinar. Engenharia Agrícola 33(2):237-248.

CONAB - Companhia Nacional de Abastecimento (2016) Acompanhamento da safra brasileira de cana-de-açúcar. CONAB, p76.

Johnson CM, Strout RR, Broyer TC, Carlton AB (1957) Comparative chlorine requirements of different species. Plant and Soil 8:327-353.

Laclau PB, Laclau JP (2009) Growth of the whole root system for a plant crop of sugarcane under rainfed and irrigated environments in Brazil. Field Crops Research 114:351-360.

Lima Gde, Nobre RG, Gheyi HR, Soares LAdosA, Silva AOda (2014) Crescimento e componentes de produção da mamoneira sob estresse salino e adubação nitrogenada. Engenharia Agrícola 34(5):854-866.

Munns R, Tester M (2008) Mechanisms of salinity tolerance. Annual Review of Plant Biology 59:651-681.

Pagariya MC, Devarumath RM, Kawar PG (2012) Biochemical characterization and identification of differentially expressed candidate genes in salt stressed sugarcane. Plant Science 184:1-13. 
Patade VY, Bhargava S, Suprasanna P (2011) Salt and drought tolerance of sugarcane under isoosmotic salt and water stress: growth, osmolytes accumulation, and antioxidant defense. Journal of Plant Interactions 6(4):275-282.

Pereira AR, Sediyama GC, Villa Nova NA (2013) Evapotranspiração. Campinas, Fundag, 323p.

Plaut Z, Meinzer FC, Federman E (2000) Leaf development, transpiration and ion uptake and distribution in sugarcane cultivars grown under salinity. Plant and Soil 218:59-69.

Santana MJde, Carvalho JdeA, Souza KJde, Sousa AMGde, Vasconcelos CL, Andrade LAdeB (2007) Efeitos da salinidade da água de irrigação na brotação e desenvolvimento inicial da cana-deaçúcar (Saccharum spp) e em solos com diferentes níveis texturais. Ciência e Agrotecnologia 31(5):1470-1476.

Silva AOda, Silva ÊFFE, Klar A (2015) Manejo da fertirrigação e salinidade do solo no crescimento da cultura da beterraba. Engenharia Agrícola 35(2):230-241.

Silva TGFda, Moura MSBde, Zolnier S, Soares JM, Vieira VJdeS, Gomes Júnior WF (2011) Demanda hídrica e eficiência do uso de água da cana-de-açúcar irrigada no semiárido brasileiro. Revista Brasileira de Engenharia Agrícola e Ambiental 15(12):1257-1265.

Simões WL, Calgaro M, Coelho DS, Santos DBdos, Souza MA (2016) Growth of sugar cane varieties under salinity. Revista Ceres 63(2):265-271.

Trentin R, Zolnier S, Ribeiro A, Steidle Neto AJ (2011) Transpiração e temperatura foliar da canade-açúcar sob diferentes valores de potencial matricial. Engenharia Agrícola 31(6):1085-1095.

Willadino L, Filho RAdeO, Silva Junior EAda, Gouveia Neto A, Camara TR (2011) Estresse salino em duas variedades de cana-de-açúcar: enzimas do sistema antioxidativo e fluorescência da clorofila. Revista Ciência Agronômica 42(2):417-422. 